\title{
El bileği ulnar taraf görüntülemesi
}

\author{
Wrist ulnar side imaging
}

\author{
Müjgan Orman¹, Ahmet Alperen Öztürk²
}

\begin{abstract}
${ }^{1}$ International Medicana Hospital, Radyoloji Kliniği, İstanbul Esenyurt Üniversitesi Sağlık Meslek Yüksek Okulu, İstanbul ${ }^{2}$ SBÜ Prof. Dr. Cemil Taşcıŏglu Şehir Hastanesi, Ortopedi ve Travmatoloji Kliniği, İstanbul
\end{abstract}

\begin{abstract}
Ulnar taraflı el bilek ağrısında, anatomik yapıların küçük olması ve semptomlara neden olabilecek bozuklukların çeşitliliği tanı ve tedaviyi zorlaştıran etmenlerdir. Ulnar taraflı el bilek ağrısının değerlendirilmesinde görüntüleme yöntemleri önemlidir. Geleneksel radyografiler, geleneksel artrografi, bilgisayarlı tomografi (BT), manyetik rezonans (MR) görüntüleme ve MR artrografi, özellikle birlikte kullanıldığında yararlı radyolojik yöntemlerdir. Geleneksel radyografiler; ulnar varyansı, karpal dizilimi, travmanın kanıtlarını ve dejeneratif değişiklikleri göstermekte, BT özellikle gizli kırıkların saptanması veya dışlanmasında, el bileğinin subluksasyon ve luksasyonunun değerlendirilmesinde, radius ve ulnanın malrotasyonunun belirlenmesinde yararlıdır. Geleneksel artrografi, triangular fibrokartilaj kompleksinin (TFKK) tam ve kısmi yırtıklarını saptamakta, bununla beraber radyokarpal ve midkarpal eklemlerin arasında patolojik iletişimi tespit etmekte kullanılabilir. MR; bağ bozulması, kıkırdak kusurları, tendon anormallikleri, gizli kırıklar ve avasküler nekrozun değerlendirilmesi için yararlıdır. MR artrografi, geleneksel artrografinin TFKK yırtıklarını saptamadaki yararına kemik iliği, bağlar ve yumuşak dokunun görselleştirilmesini ekler. MR artrografi, geleneksel artrografinin yerini almıştır. Bu makale, ulnar taraflı el bilek ağrısında görüntüleme yöntemlerini gözden geçirmektedir.
\end{abstract}

Anahtar sözcükler: radyografi; bilgisayarlı tomografi; manyetik rezonans görüntüleme; artrografi; ultrasonografi
Small anatomical structures and the variety of disorders that can cause symptoms are factors that make diagnosis and treatment difficult in ulnar side pain. Imaging methods are important in the evaluation of ulnar sided wrist pain. Conventional radiographs, conventional arthrography, computed tomography (CT), magnetic resonance imaging (MRI) and magnetic resonance (MR) arthrography are useful radiological methods especially when used together. Conventional radiographs are useful in showing ulnar variance, carpal alignment, evidence of trauma and degenerative changes. CT is especially useful in detecting or excluding occult fractures, in evaluating the subluxation and luxation of the wrist, and in determining the malrotation of the radius and ulna. Conventional arthrography can be used to detect complete and partial tears of the triangular fibrocartilage complex (TFCC), as well as to detect pathological communication between the radiocarpal and midcarpal joints. MRI is superior for evaluation of ligament disruption, cartilage defects, tendon abnormalities, occult fractures and avascular necrosis. MR arthrography adds visualization of bone marrow, ligaments and soft tissue to the benefit of conventional arthrography in detecting TFCC tears. MR arthrography has replaced conventional arthrography. This article reviews imaging modalities for ulnar sided wrist pain.

Key words: radiography; computed tomography; magnetic resonance imaging; arthrography; ultrasonography
U Inar taraflı el bilek ağrısında tanı, uzun zamandır hem radyologlar hem de el cerrahları için zorlayıcıdır. Anatomik yapıların küçük olması, semptomlara neden olabilecek bozuklukların çeşitliliği tanı ve tedaviyi zorlaştıran etmenlerdir.

Ulnar taraflı el bilek ağrısının değerlendirilmesinde görüntüleme yöntemlerinden yararlanılır. Geleneksel radyografiler; ulnarvaryansı, karpal dizilimi, travmanın kanıtlarını ve dejeneratif değişiklikleri gösterebilir. Bilgisayarlı tomografi (BT) özellikle gizli kırıkların saptanması veya dışlanmasında, el bileğinin subluksasyon ve luksasyonunun değerlendirilmesinde, radius ve ulnanın malrotasyonunun belirlenmesinde yararlıdır. ${ }^{[1]}$ Geleneksel artrografi (tek, çift veya üç bölmeli), triangular fibrokartilaj kompleksinin (TFKK) tam ve kısmi yırtıklarını saptamakta kullanılabilir. Bununla beraber

- Illetişim adresi: Dr. Müjgan Orman, Beylikdüzü Cd. No: 3, 34520 Beylikdüzü, İstanbul

Tel: 0532 - 6183974 e-posta: mujganyildizorman@gmail.com

- Geliș tarihi: 8 Mayıs $2021 \quad$ Kabul tarihi: 31 Mayıs 2021

ORCID iD: Müjgan Orman, 0000-0002-9629-0211 • Alperen Öztürk, 0000-0002-1777-9060 

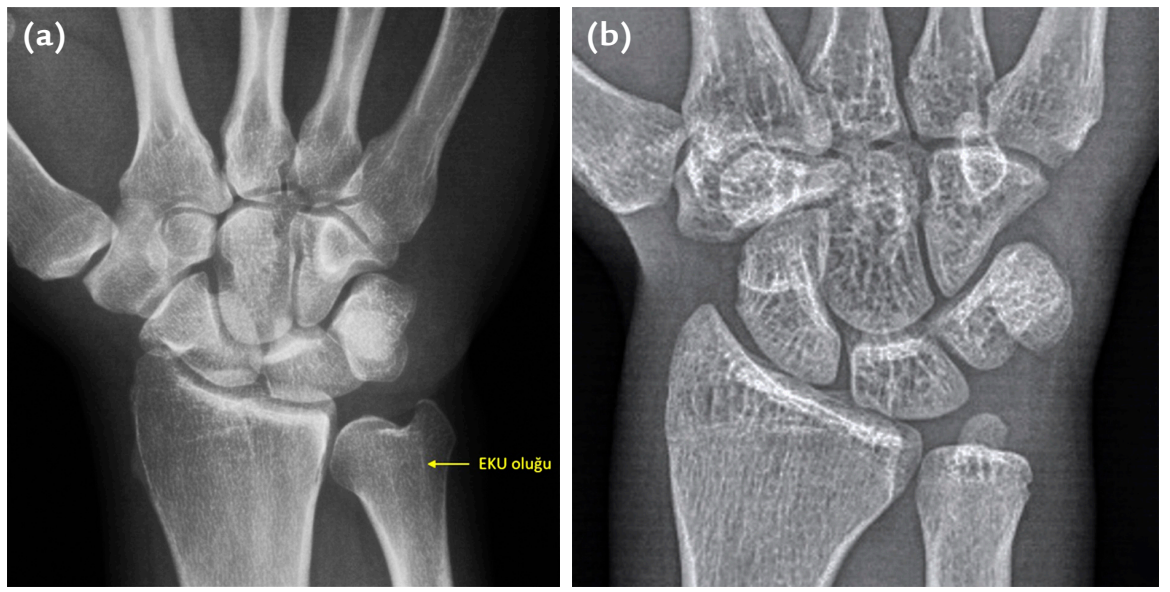

Şekil 1. a, b. El bileği: Arka-ön (postero-anterior, PA) (a) ve ön-arka (antero-posterior, AP) (b) radyografisi. Ulna stiloidi PA pozisyonda ulna lateralinde, AP görüntüde ulnar başın merkezindedir. Ekstansör karpi ulnaris (EKU) oluğu PA grafide (a) ulna stiloidi tabanından başlayan ince soluk çizgi olarak görülmektedir.
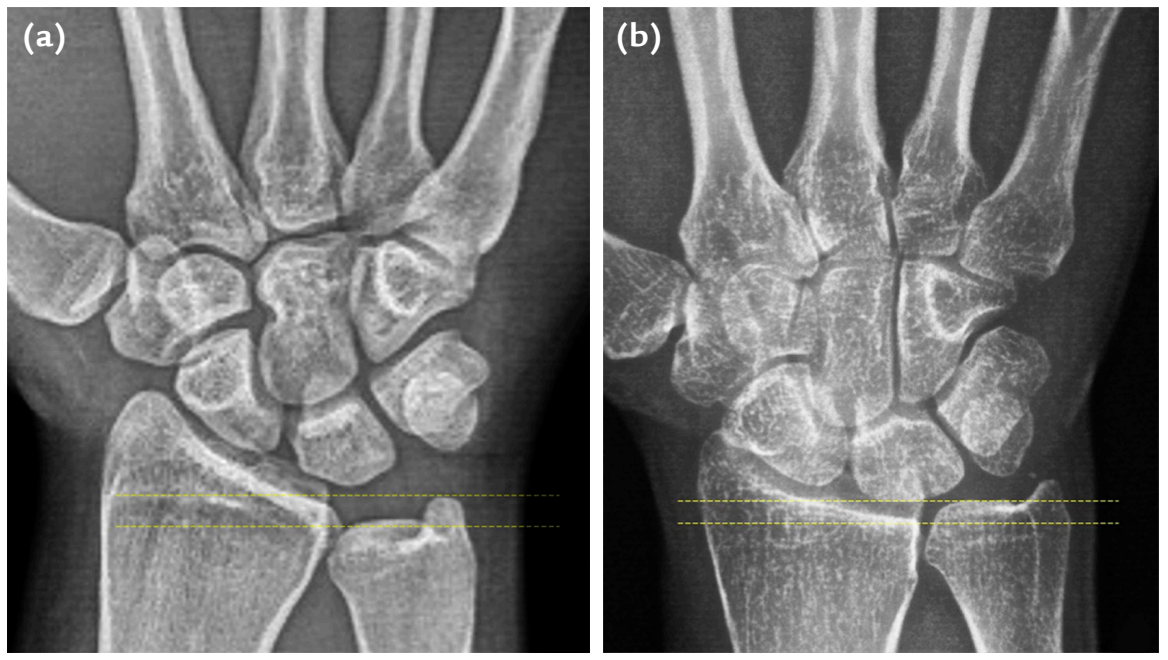

Şekil 2. a, b. Ulnar varyans: Negatif ulnar varyans (a) ve pozitif ulnar varyans (b). Radyolunat fossa hizasından radius şaftına dik çekilen çizgiyle ulna eklem yüzü hizasından ulna cismine (şaftına) dik çekilen çizgi arası mesafe 1 mm'den az olmalıdır.

radyokarpal ve midkarpal eklemlerin arasında patolojik iletişimi tespit edebilir. Manyetik rezonans (MR) görüntüleme; bağ bozulması, kıkırdak kusurları, tendon anormallikleri, gizli kırıklar ve avasküler nekrozun değerlendirilmesi için yararlıdır. Manyetik rezonans artrografi, geleneksel artrografinin TFKK yırtıklarını saptamadaki yararına kemik iliği, bağlar ve yumuşak dokuyu görselleştirilmesini ekler. ${ }^{[2]}$

\section{ULNAR TARAFLI BILEK AĞRISI IÇiN GÖRÜNTÜLEME YÖNTEMLERI}

\section{Radyografiler}

Kırıklar, enflamatuvar artrit, osteoartrit veya konjenital anomali gibi hastalıklarda klinik değerlendirme radyografilerle başlar. Genellikle el bileğinin arka-ön (postero-anterior, PA) ve yan görünümleri alınır. Görüntüler; hasta otururken, ön kol nötr pozisyonda, dirsek $90^{\circ}$ fleksiyonda ve omuz $90^{\circ}$ abduksiyonda alınmalıdır. PA radyografide; Gilula çizgilerine, ulnar varyansa, karpal yükseklik oranına ve karpal instabilite kanıtlarına dikkat gösterilmelidir. PA grafide ulna stiloid, ulnar sınırdayken ön-arka (antero-posterior, AP) grafide bunun aksine ulnar başın merkezinde yerleşir. Ekstansör karpi ulnaris (EKU) oluğu, PA grafide ulnar stiloidin tabanından proksimale uzanan soluk bir çizgi olarak görünür (Şekil 1). Yan radyografide karpal instabilite; skafolunat, kapitolunat ve lunotrikuetral açıların değerlendirilmesiyle saptanabilir. Ulnar varyans, radius ve ulna uzunluklarının anatomik varyasyonlarıdır. Kural olarak PA grafide, lunat eklem hizasında radius ve ulna eklem yüzleri aynı seviyede olmalıdır. Radyolunat fossa hizasından radius şaftına dik çekilen çizgiyle ulna eklem yüzü hizasından ulna şaftına dik çekilen çizgi arası mesafe $1 \mathrm{~mm}$ 'den az olmalıdır. Buna nötral varyans denir. Ulna daha proksimalde ise negatif ulnar varyans, daha distalde ise pozitif ulnar varyans olarak adlandırılmaktadır (Şekil 2). 

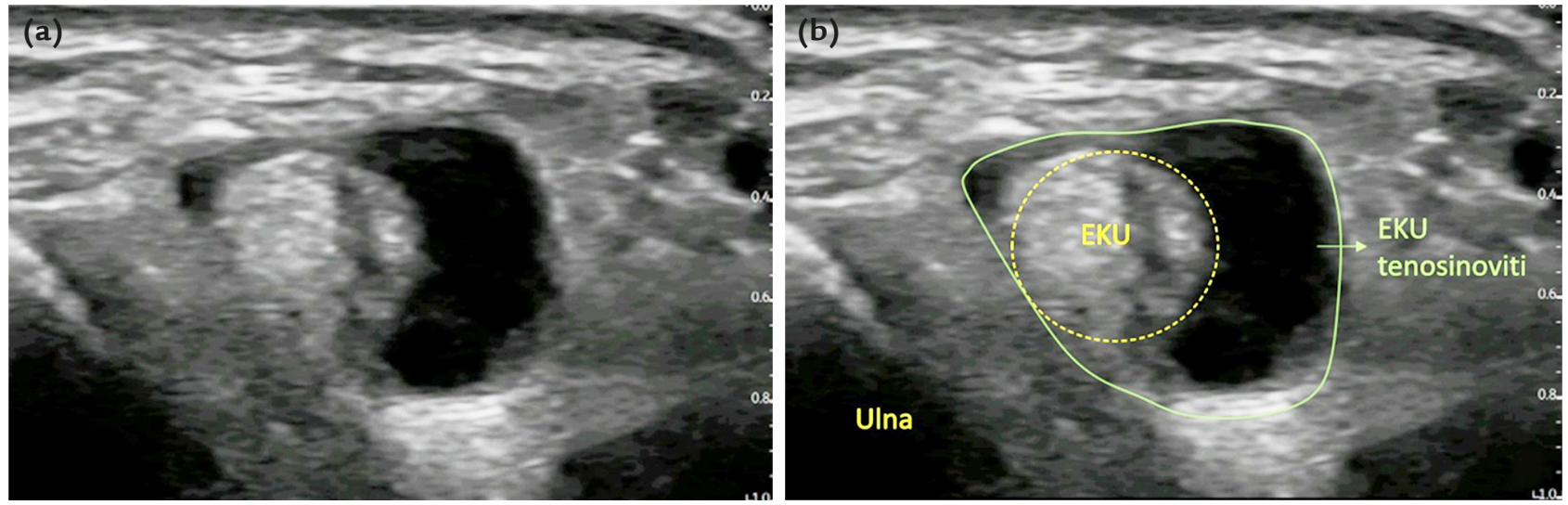

Şekil 3. a, b. El bileğinde ekstansör karpi ulnaris ultrasonografi (US) görüntüsü: Ekstansör karpi ulnaris (EKU) hiperekoik ve çevresindeki sinovit hipoekoik olarak görülmekte (a) ve işaretlenmiş hali (b).

Ön kol rotasyonundaki değişiklikler çeşitli radyografik indekslerin ölçümünü etkileyebileceğinden, PA ve yan radyografilerin ön kol nötr rotasyonda olacak şekilde yapılması önemlidir. Örneğin, pronasyon ulnar varyansı artırırken, supinasyon ise azaltır. ${ }^{[3]}$

Karpal kemiklerdeki hasarın tam olarak belirlenmesi için ek incelemeler yapmak gerekebilir. Otuz derece pronasyonda oblik radyografi ulnar tarafin dorsalinin değerlendirilmesine izin verirken, ters oblik görünüm ( $30^{\circ}$ supinasyon), ulnar tarafın volar yüzünün ve pisotrikuetral eklemin değerlendirilmesine izin verir. Karpal tünel radyografisi, hamat kancasını ve olası pisotrikuetral patolojiyi görselleştirmek için kullanılır. Karpal tünel grafisi için el bileği yaklaşık $35^{\circ}$ dorsale doğru bükülür ve $X$-ışını bileğin ön tarafına teğet olarak yollanır. En iyi değerlendirme için standartlaştırılmış pozisyonlama ve yüksek kaliteli radyografiler gereklidir.

\section{Artrografi}

Artrografi, interosseöz bağların yırtılmalarının ve TFKK yırtıklarının değerlendirilmesi için tercih edilir. Manyetik rezonans artrografi yaygınlaşmadan önce, ulnar taraflı el bilek ağrısının sebebi olan TFKK'nin perforasyonlarını saptamak için üçlü enjeksiyonlu artrografi "altın" standart olarak kabul edilirdi. ${ }^{[2,4]}$ Son yıllarda, TFKK sorunlarını saptamada artrografinin yerini büyük ölçüde $M R$ görüntüleme ve $M R$ artrografi almıştır.

Üç bölmeli artrografide, floroskopi eşliğinde ilk olarak midkarpal ekleme enjeksiyon yapılır. [1,5] Midkarpal ekleme 3-4 ml çözelti enjekte edilir. Radyokarpal eklem ile iletişim varsa, 3-4 ml çözelti daha enjekte edilir. Radyokarpal eklemden distal radyoulnar (DRU) ekleme de geçiş oluyorsa 1-2 $\mathrm{ml}$ çözelti daha eklenir. Toplamda verilen solüsyon miktarı 7-9 ml'yi aşmamalıdır. Herhangi bir iletişim yoksa, midkarpal eklem enjeksiyonundan sonra ayrı ayrı radyokarpal ekleme 3-4 ml, DRU ekleme 1-2 ml solüsyon enjekte edilir.

\section{Ultrasonografi (US)}

Kas-iskelet sistemi değerlendirmesinde US giderek daha fazla kullanılmaktadır. Ultrasonografi görüntü kalitesi daha yüksek frekanslı ve daha küçük problarla artmıştır. ${ }^{[1,6]}$ Ultrasonografi, kemik patolojisinin değerlendirilmesinde yardımcı olmasa da yumuşak doku anatomisi hakkında değerli bilgiler sağlar. ${ }^{[1]}$ Ultrasonografi görüntülemesinin avantajları; iyonlaştırıcı radyasyon içermemesi, invaziv olmaması, taşınabilirliği ve düşük maliyetidir. Dinamik ve gerçek zamanlı değerlendirme ve Doppler görüntüleme diğer üstünlükleridir. Ultrasonografi, yabancı cisimlerin tespitinde ve tendonları, bağları, damarları ve sinirleri etkileyen çeşitli travmatik lezyonların görüntülenmesinde yararlıdır. Bunların yanı sıra akut ve kronik tenosinovit ile el ve el bileğinin dejeneratif ve enflamatuvar tendon hastalıklarının güvenilir bir şekilde tanımlanmasına olanak sağlar (Şekil 3). ${ }^{[7]}$ Bunlara ek olarak tendon kopmalarını da etkili bir şekilde teşhis edebilir.

\section{Bilgisayarlı Tomografi (BT)}

Ulna stiloid, pisiform, beşinci metakarp tabanı ve hamat kırıkları ulnar taraflı el bileği ağrısının nedenlerindendir. Geleneksel radyografi şüpheli karpal kırık ve çıkıkların değerlendirilmesinde birincil görüntüleme yöntemi olsa da BT giderek daha önemli hale gelmektedir. Bilgisayarlı tomografi özellikle gizli kırıkların saptanması veya dışlanmasında, evreleme amacıyla kırıkların boyutunu belgelemek ve el 

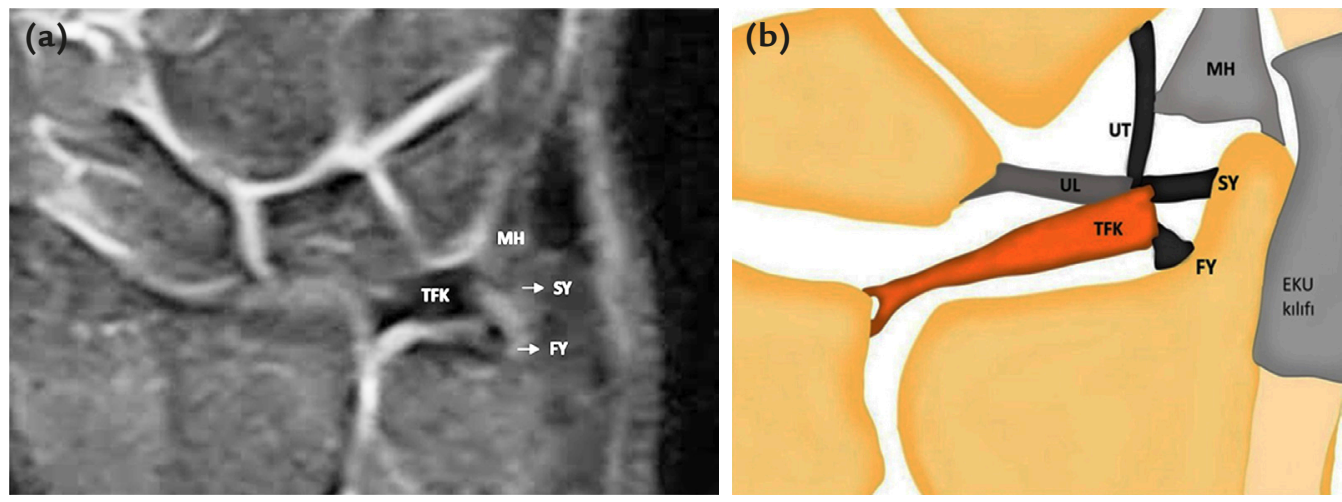

Şekil 4. a, b. Triangular fibrokartilaj (TFK) anatomisi: Koronal yağ baskılı T2 ağırıklı görüntüde triangular fibrokartilaj kompleks (TFKK) görünümü (a) ve TFKK şematik anatomisi (b) $(\mathrm{MH}$, menisküs homolog; UL, ulnolunat bağ; UT, ulnotrikuetral bağ; SY, stiloid yapışma yeri; $\mathrm{FY}$, fovea yapışma yeri).

bileğinin subluksasyon ve luksasyonunun yanı sıra radius ve ulnanın malrotasyonunu belirlemek için yararlıdır. Bunlara ek olarak, çok düzlemli (iki boyutlu) ve hacimsel (üç boyutlu) reformasyonla incelemeyi hızlandırır ve keskinleştirir. ${ }^{[8]}$ Standart aksiyel görüntüler olgu yüz üstü yatar pozisyonda, el başın ilerisinde, 1 ya da 2 mm'lik kesitler alınarak elde edilir. Sonrasında bu görüntülere rekonstrüksiyon da yapılabilir.

\section{Bilgisayarlı Tomografik Artrografi}

Bilgisayarlı tomografik artrografi, kemik anatomisinin ayrıntılı görüntüsünü, el bileğinin bağ yapılarının görüntüsüyle birleştirir. Ek olarak, TFKK yırtıkları bulundukları lokalizasyona göre ayırt edilebilir. Tek bölmeli (radyokarpal eklem), çift bölmeli (radyokarpal+midkarpal veya radyokarpal+distal radyoulnar eklem) veya üç bölmeli enjeksiyon tekniği kullanılabilir. ${ }^{[9]}$

Hastanın el bileği başından ileride olacak şekilde masaya yüzüstü yatırılarak veya kolu abduksiyon ve dirseği fleksiyonda, avuç içi masaya bakacak şekilde bir taburede oturtularak enjeksiyon yapılabilir. Tüm el bilek bölmelerinin enjeksiyonu için dorsal yaklaşım kullanılır. El bileğinin altına bir sünger veya yumuşak bir havlu yerleştirilir. Bileğin dorsal yönü steril olarak hazırlanır ve dikey floroskopi kılavuzluğunda 24 gauge iğne ile eklem boşluklarına ortalama olarak toplam $5 \mathrm{ml}$ iyotlu kontrast madde enjekte edilir. Kontrast ortamının aşırı seyreltilmesini önlemek için hasta hemen BT odasına yönlendirilir. Hasta "süpermen" pozisyonunda yatırılır. Mümkün olan en ince kesit kalınlığı $(0,5 \mathrm{~mm})$ kullanılır. ${ }^{[10]}$

\section{Manyetik Rezonans (MR) Görüntüleme}

Manyetik rezonans görüntüleme, eklemlerin iç düzensizliğinin değerlendirilmesinde önemli bir rol oynar ve el bileği bozukluklarının teşhisi için mükemmel bir yöntemdir. Bilgisayarlı tomografi üstün kemik ayrıntı sağlarken, MR yumuşak doku kontrastı ve kemik ödemi gibi kemik iliği değişiklikleri için daha fazla duyarlılığa sahiptir. Bu nedenle özellikle gizli kırıkların ve stres kırıklarının değerlendirilmesi için yararlıdır. Yeterli MR görüntüleme için ince ve devamlı kesitler gereklidir, çünkü el bileğinin etrafındaki büyük bağların çoğu 1-2 mm'den daha incedir. Bu nedenle, el ve el bileğinin normal ve anormal yapılarını değerlendirmek için yüksek çözünürlüklü MR görüntüleme gereklidir. ${ }^{[11]}$ Yüksek çözünürlüklü MR elde etmek için, yüksek sinyal/gürültü oranı gereklidir. Üç tesla gibi yüksek manyetik alanlı MR, böyle bir oranın elde edilmesini sağlar.

Hasta ilgili el bileği başının ilerisinde olacak şekilde yüzüstü ("süpermen" pozisyonu) veya el bileği hastanın yanında sırtüstü pozisyona yerleştirilerek çekilir. Sırtüstü pozisyon hasta için daha rahattır ve bu pozisyonda hasta daha az hareket eder. ${ }^{[12]}$

Manyetik rezonans görüntülemede önemli olan, eklemi birden çok düzlemde (aksiyel, koronal ve sagittal) ve farklı doku kontrastıyla incelemektir. Triangular fibrokartilaj kompleks ve proksimal karpal interosseöz bağlar (skafolunat ve lunotrikuetral bağlar) en iyi koronal planda gösterilir. Bu yapılar T1 ve T2 ağırıklı sekanslarda düşük sinyal yoğunluğundadır. Koronal düzlemde el bileğinin çeşitli intrinsik ve ekstrinsik, dorsal ve volar bağları da görülür (Şekil 4). Sagittal düzlemde tüm fleksör ve ekstansör tendonlar ve bunların insersiyonları radyoskafokapitat, radyolunotrikuetral ve dorsal radyolunat gibi bağlar görülebilir. Aksiyal düzlemde çeşitli bağ ve tendonlar kesitsel olarak görüntülenir ve bunların kemik yapılar ile ilişkisi değerlendirilir. ${ }^{[12]}$ Manyetik rezonans görüntülemede TFKK altında veya DRU eklemde sıvı bulunması TFKK tam kat yırtılmasını gösterir.

\section{Manyetik Rezonans (MR) Artrografi}

Manyetik rezonans artrografi, geleneksel MR ve artrografinin avantajlarını birleştirir. Direkt MR artrografi, özellikle bilek bağlarını ve TFKK'yi değerlendirmek 

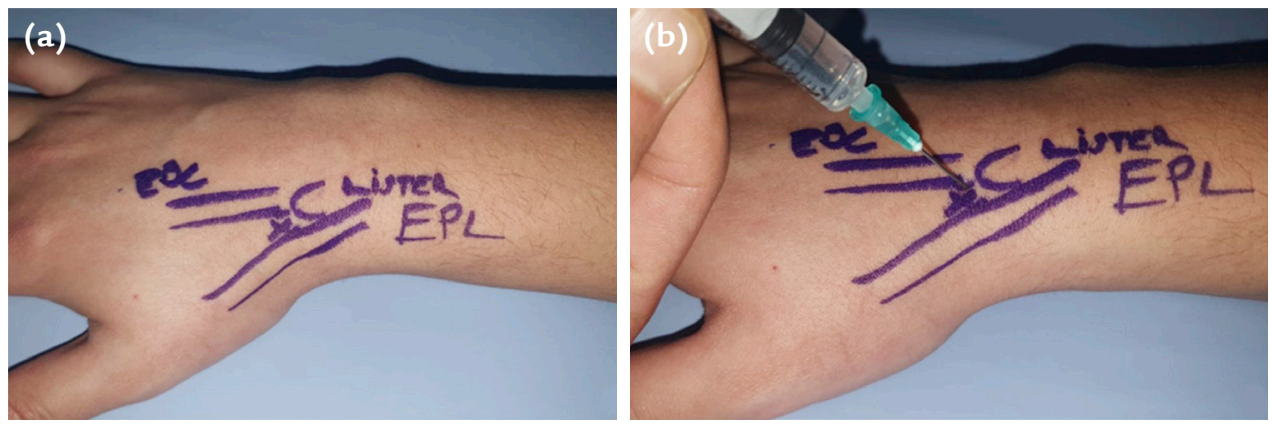

Şekil 5. a, b. Radyokarpal ekleme kontrast madde verilmesi: Lister çıkıntısı, ekstansör pollisis longus (EPL) tendonu ve ekstansör dijitorum kommunis (EDK) tendonu bulunarak işaretlenir. Bu üç yapının birleşim yerinin hemen distalindeki yumuşak nokta enjeksiyon noktasidır (a). Kontrast madde $15^{\circ}$ açıyla enjekte edilir (b).
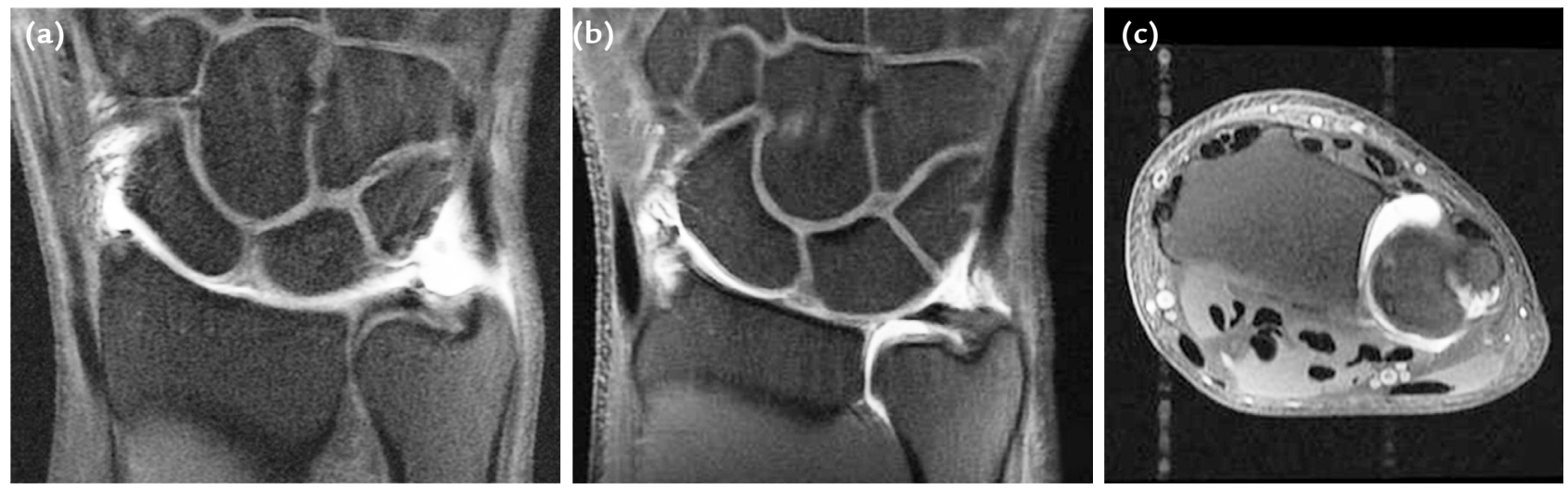

Şekil 6. a-c. Manyetik rezonans artrografi: T2 koronal kesitte triangular fibrokartilaj kompleks (TFKK), menisküs homolog, ulnolunat ve ulnotrikuetral bağ yırtığına bağlı kontrast maddenin el bileğinde dağılımı (a). T2 koronal ve aksiyel kesitte total TFKK yırtığına bağlı kontrast maddenin menisküs homolog ve distal radyoulnar eklem aralığına geçişi (b ve c). (Dr. Kahraman Öztürk'ün arşivinden izni ile alınmıştır)

için kullanışlıdır. En çok tercih edilen radyokarpal enjeksiyondur. Radyokarpal eklem içine enjeksiyon hem TFKK'nin hem de iç bağların yırtıklarının değerlendirilmesine yardımcı olur. Ancak bölmeler arasında iletişim yoksa ve TFKK'de kısmi bir yırtılma endişesi varsa, distal radyoulnar ekleme de enjeksiyon yapılmalıdır. Midkarpal enjeksiyon, interosseöz bağların incelenmesine yardımcıdır. Karmaşık semptomları olan ve klinik muayenede ağrı kaynağı belirlenemeyen hastalarda üç bölmeli enjeksiyon yapılabilir.

El bileğinde üçlü (midkarpal, radyokarpal ve distal radyoulnar eklem), ikili (radyokarpal+midkarpal veya radyokarpal+distal radyoulnar) ve tek (radyokarpal) kompartmanlı MR artrografi kullanılır. ${ }^{[13,14]}$ Kontrast maddenin eklem içi enjeksiyonu genellikle steril olarak floroskopi veya US kılavuzluğunda gerçekleştirilir. Manyetik rezonans artrografi için, bir dizi gadolinyum seyreltme kullanılabilmesine rağmen, 1:200 seyreltme çoğu durumda mükemmel görüntüleme sağlar. Karışım iyotlu kontrast madde, lokal anestezik ve salin solüsyonu içerir. Iyotlu kontrast madde ilavesi, enjeksiyon sırasında floroskopik görüntülemeye izin verir. Lokal anestezik hasta konforunu artırır ve MR görüntülemede hareket artefaktlarını azaltır. Salin
$(10 \mathrm{ml})$, iyotlu kontrast madde $(5 \mathrm{ml})$ ve \%1 lidokain $(5 \mathrm{ml})$ içeren $20 \mathrm{ml}$ solüsyon içine gadolinyum solüsyonu $(0,1 \mathrm{ml})$ eklenir. Geleneksel olarak üç kompartmanlı MR artrografi, artrografi başlığı altında anlatılan şekilde yapılır; sonrasında hasta MR görüntüleme cihazına alınır. Buna karşın floroskopi eşliğinde MR artrografi kullanışlı bulunmayabilir ya da floroskopi erişimi olmayabilir. Bu durumda klinik ve önceki görüntülerde şüphe durumuna göre kontrast maddenin verileceği kompartmanlar belirlenir. Ulnar taraflı TFKK yırtık şüphesi için radyokarpal (Şekil 5) ve DRU ekleme; interkarpal bağ yırtık şüphesinde midkarpal ekleme enjeksiyonlar yapılır.

Yüksek çözünürlüklü el bilek koili, daha dar görüş alanı $(3-10 \mathrm{~cm})$ ve daha ince kesit kalınlığı $(1-2 \mathrm{~mm})$ sağlar. ${ }^{[11]}$ Koronal, aksiyel ve sagittal planda görüntüleme yapılmalıdır. Yağ baskılanması, MR artrografide çok önemlidir. Bunun nedeni yağ ve gadolinyum T1 ağırlıklı görüntülerde benzer sinyal yoğunluklarına sahiptir ve bu da teşhisi zorlaştırır. Yağ baskılama ile yağdan gelen sinyali azaltır ve kontrast solüsyondan gelen sinyal korunur. Üç boyutlu gradyan eko görüntüleri TFKK ve bağların değerlendirilmesinde yardımcıdır (Şekil 6). ${ }^{[14]}$ 

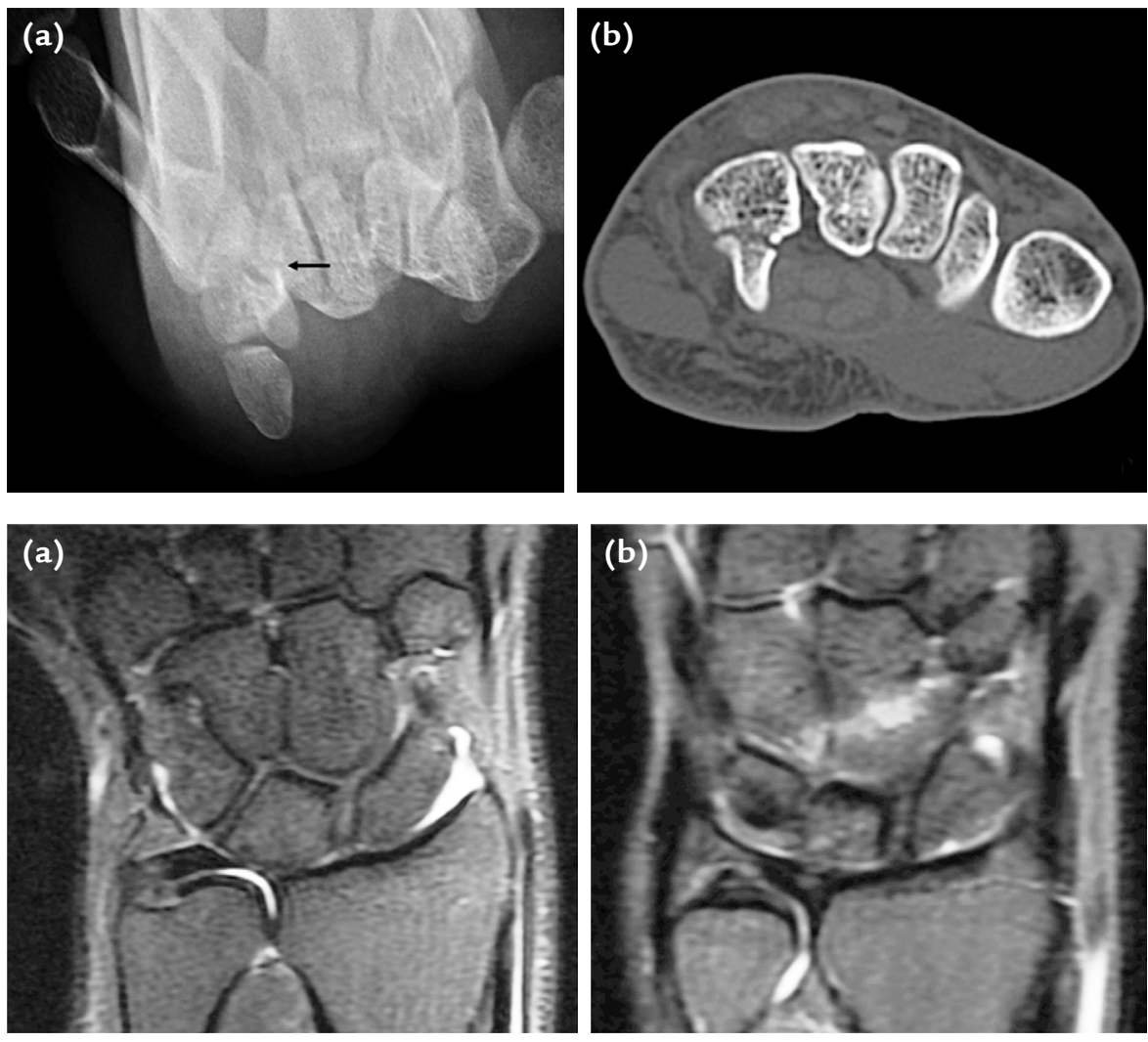

Şekil 7. a, b. Hamat kırığı: Karpal tünel grafisi (siyah ok, kırık hattı) (a). Aksiyal kesit BT görüntüsü (b).

\section{PATOLOJILER}

\section{Hamat Kırığı}

Hamat kırıkları, karpal kemik kırıklarının \%2'sini oluşturur ve genellikle el bileği volar tarafına doğrudan darbeye bağlı gelişir. Bu özellikle hamat kanca kırıkları için geçerlidir. Hamat kancasının kırıklarını PA ve lateral grafilerde görmek zor olabilir. Klinik olarak hamat kanca kırığından şüpheleniliyorsa, karpal tünel grafisi ve el bileği dorsifleksiyonda supinasyonlu oblik grafi çekilmelidir. Kortikal gölgenin yokluğu, sınırların belirsizleşmesi veya skleroz varlığı kanca kırığını düşündürür. Karşılaştırma için diğer el bileğinin radyografik görüntüsü alınmalıdır. Klinik sorun devam ederse ve radyografiler şüpheli ise BT veya MR önerilir (Şekil 7). Şüpheli kırıkların değerlendirilmesinde, el bileğinin aksiyel BT kesitleri ve sagittal reformat görüntüleri rutin olarak uygulanmalıdır. Gözden kaçan kronik bir hamat kancası kırığı; ulnar sinir felci, ulnar arter kompresyonu, dördüncü ve beşinci fleksör tendonlarının yırtılmasıyla ortaya çıkabilir. ${ }^{[15]}$

\section{Triangular Fibrokartilaj Kompleks (TFKK) Yaralanmaları}

Triangular fibrokartilaj kompleks, distal radyoulnar (DRU) eklemde stabilite sağlar. Triangular fibrokartilaj kompleks, travma veya tekrarlayan döngüsel hareketlerle zarar görebilir. Triangular fibrokartilaj kompleksin yırtıkları travmatik veya dejeneratif olabilir. Travmatik yırtıklar, dejeneratif yırtıklara göre radyale daha yakın olma eğilimindedir. Dejeneratif yırtıklar, genellikle bileğin ulnar tarafındaki kronik yüklenmeden kaynaklanır ve eklem diskinin daha ince olan merkez kısmında meydana gelme eğilimindedir. ${ }^{[16]}$

Manyetik rezonans, geleneksel artrografi ve MR artrografi, TFKK'yi görüntülemede en kullanışlı yöntemlerdir. Manyetik rezonans ile, TFKK en iyi koronal planda görüntülenir. Triangular fibrokartilaj kompleks, T1-T2'de düşük sinyal yoğunluğundadır. Dejeneratif lezyonlarda T1, T2 ağırlıklı ve yağ baskılı T2 ağırlıklı taramalarda artmış sinyal görülür. Yırtıklarda ise T1 ağırlıklı görüntülerde düşük sinyal, T2 ağırlıklı ve yağ baskılı T2 görüntülerde yüksek sinyal görülür. Kısmi yırtıklarda, sinyal anormalliği yalnızca bir eklem yüzeyine uzanırken, tam kat yırtıklarda sinyal anormalliği hem proksimal hem de distal eklem yüzeylerine uzanır. Manyetik rezonans artrografide, DRU eklemde kontrast bulunması TFKK tam kat yırtığı için önemli bir kanıttır. (Şekil 8). ${ }^{[16,17]}$ 

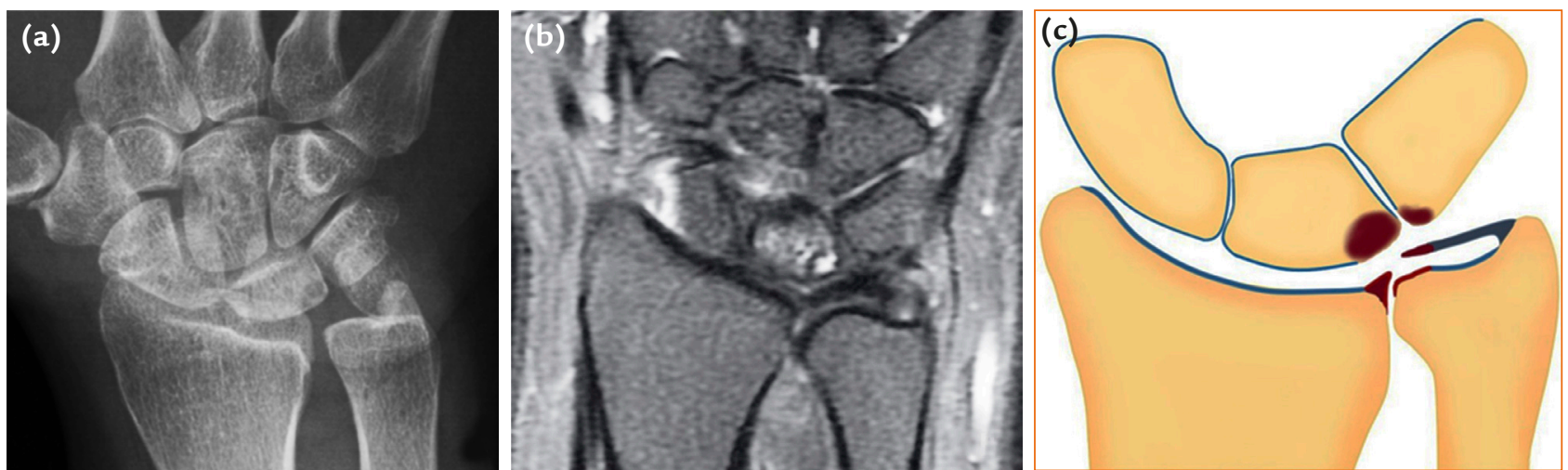

Şekil 9. a-c. Ulnar impaksiyona ait radyolojik görüntüleme: Ulnar baş, lunatum ulnar yüzü ile trikuetrum radyal yüzünde kondromalazi ve triangular fibrokartilajda (TFK'de) santral perforasyon; postero-anterior (PA) radyografi, ulnar pozitif varyans ve lunatum ulnar yüzünde subkondral radyolusent kist (a), T2 ağırlıklı manyetik rezonans (MR) görüntülemede lunatum ulnar yüzünde subkondral kist (b), şematik görüntü (c).
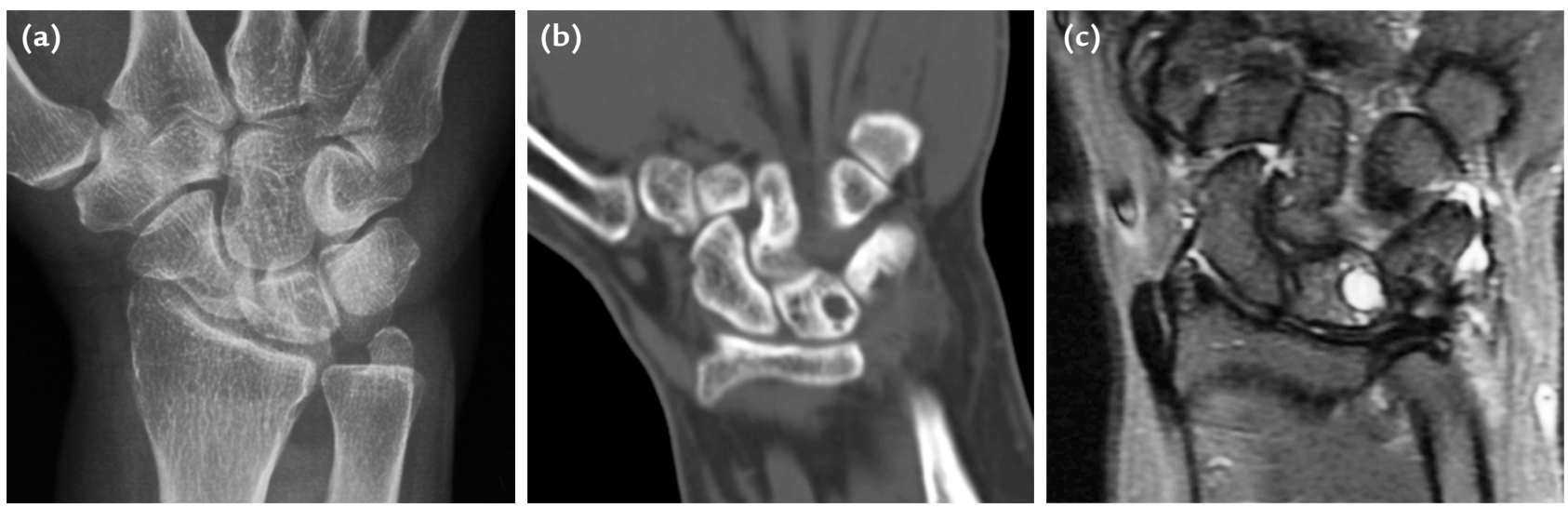

Şekil 10. a-c. Lunatum ulnar tarafında yerleşen intraosseöz ganglion kisti: Arka-ön radyografisi (a), bilgisayarlı tomografi (BT) koronal kesit (b) ve manyetik rezonans (MR) görüntüleme T2 koronal kesit (c).

\section{Ulnar İmpaksiyon Sendromu}

Ulnar impaksiyon sendromu, el bileğinde ulnar tarafta ağıı ve radyokarpal eklem hareketlerinde kısıtlama ile karakterize bir durumdur. Karpal kemik ile ulnar baş arasındaki sıkışmadan kaynaklanır. Sıklıkla ulna radiustan daha uzun olduğunda gelişir. Konjenital pozitif ulnar varyans, yanlış kaynamış distal radius kırıkları, radyal büyüme plağının erken kapanması ve radius başının eksizyonu sonucu olabilir. Radyografi, distal radius kırı̆̆ını, önceki bir cerrahi prosedürü veya distal radius büyüme plağının erken kapanmasını takiben radius kısalığını gösterebilir. Ayrıca proksimal lunat, trikuetrum ve ulna başının, ulnar tarafında skleroz veya kistik değişiklikler de görülebilir. Manyetik rezonans görüntüleme, sadece kemiğin anatomik anormalliğini değil, aynı zamanda ulnar impaksiyon sendromundaki kıkırdak dejenerasyonu veya defekti, kemik iliği ödemi, subkondral kistler ve etkilenen bölgedeki sklerotik değişiklikler gibi ikincil değişiklikleri saptamak için de yararlıdır. Bununla beraber, TFKK ve lunotrikuetral ligament yırtıkları gibi eşlik eden patolojiler kolaylıkla gösterilebilir (Şekil 9). ${ }^{[18,19]}$

\section{Lunatum İntraosseöz Ganglion Kisti}

Karpal kemiklerin intraosseöz ganglion kistleri yaygındır ve lunatumda özellikle radyalde oluşur. Kistler genellikle kemiğin subkondral bölgesinde bulunur. Kemikle sınırlı olabilir veya yumuşak doku ganglion kistinin kemiğe uzanmasından kaynaklanabilir. Çoğu intraosseöz ganglion kisti semptomsuzdur ve başka nedenlerle yapılan el bilek görüntülemesinden sonra tesadüfen bulunur. Radyografide ve BT'de ince sklerotik kenarlı, radyolusent litik lezyon olarak görülür. Manyetik rezonans, radyografiler normal olduğunda intraosseöz ganglion kistlerini gösterebilir. Manyetik rezonans T1 hipointens ve T2 görüntülerde hiperintens homojen lezyonlar olarak görülür (Şekil 10). ${ }^{20]}$ 

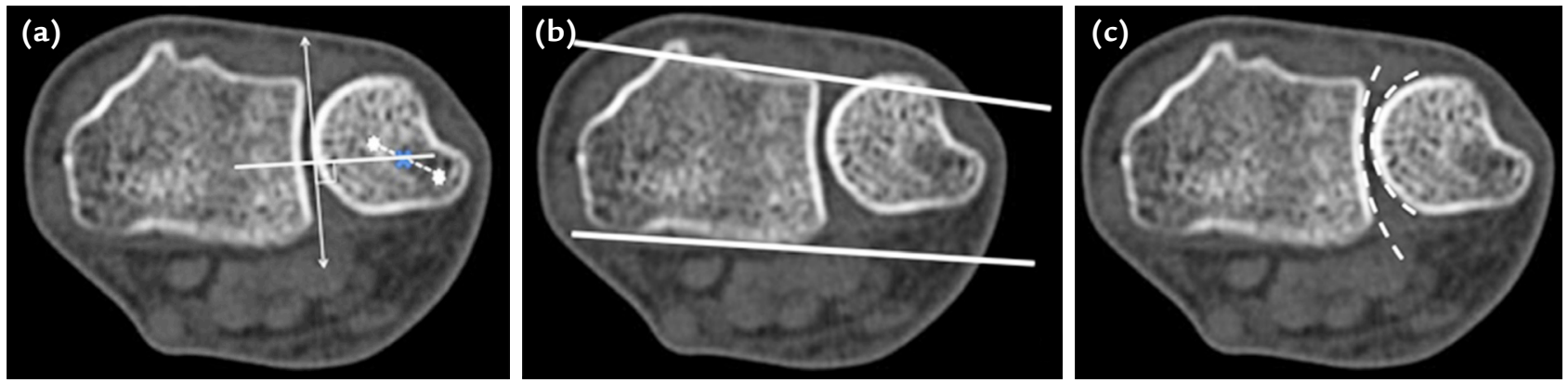

Şekil 11. a-c. Üst merkez yöntemi: ulna başı ortası ile stiloid ortası arasındaki nokta belirlenir. Bu nokta distal radyoulnar (DRU) eklemin rotasyon merkezidir. Bu noktadan radius sigmoid çentiğe teğet geçen çizgiye dik çizilir. Bu dik çizgi sigmoid çentiğe teğet geçen çizginin ortasından geçmelidir (a). Mino (radyoulnar çizgi) yönteminde; distal radiusun hem volar hem de dorsal kenarı boyunca ulna başına uzanan birer çizgi çizilir ve ulna başının \%25'inden fazlası bu hatlarda volar veya dorsal yer değiştiriyorsa instabilite mevcuttur (b). Uyum yöntemi, ulna başı ve sigmoid çentik boyunca çizilen yaylara dayanır ve bu yaylar arasındaki mesafe eğri boyunca herhangi bir noktada değişirse instabilite vardır (c).

\section{Ulnar Stiloid İmpaksiyon}

Ulnar stiloid impaksiyonu, uzun ulnar stiloid prosesine ya da kaynamamış stiloid kırığına bağlıdır. Ulna stiloidinde ve proksimal trikuetrumda kondromalazi ile sonuçlanabilir. Lunotrikuetral (LT) eklem instabilitesine yol açabilir. Geleneksel radyografiler uzun stiloidi veya kaynamamış stiloid kırığını gösterir. Ulnar stiloid, toplam uzunluğu $6 \mathrm{~mm}$ 'den fazla olduğunda veya ulnar stiloid indeksi (stiloid uzunluğu- ulnar varyans/ulnar baş genişliği) 0,12'den büyük olduğunda uzun kabul edilir. ${ }^{[21,22]}$ Manyetik rezonans, ulnar stiloid impaksiyonuna bağlı kıkırdak dejenerasyonu, kemik iliği ödemi, subkondral kistler, proksimal trikuetrumda sklerotik değişiklikleri gösterebilir. Manyetik rezonans artrografi, ulnar stiloid impaksiyon sendromuna bağlı TFKK hasarının değerlendirilmesine yardımcı olabilir. ${ }^{[16]}$

\section{Hamatolunat İmpaksiyon}

Tip 1 lunat, hamat ile eklem yapmak için bir yüzeye sahip değildir. Tip 2 lunat ise, hamatın proksimal kutbu ile eklemlenen ikinci bir fasete sahiptir ve popülasyonun yaklaşık \%44 ila \%73'ünde bu tiptedir. ${ }^{[23]}$ El bileği tam ulnar deviasyonda kullanıldığında bu iki kemiğin tekrarlayan sıkışması sonucu kondromalazi gelişir. Tam ulnar deviasyondaki el bilek PA radyografisi, hamat ve lunat kemiklerin sürtünmesini gösterebilir. Manyetik rezonans incelemede kemik iliği ödemi, kondromalazi ve hamatın proksimal kutbunda veya distal/medyal lunatta subkondral kistler görülür. ${ }^{[24]}$

\section{Distal Radyoulnar (DRU) Eklem}

Distal radyoulnar (DRU) eklem, radius sigmoid çentiği, ulna başı ve TFKK'den oluşur. Distal radyoulnar eklemin stabilitesi eklem morfolojisi, kapsül, dorsal ve volar radyoulnar bağlar, interosseöz membran, EKU ve pronator kuadratus tarafından sağlanır. Distal radyoulnar eklem instabilitesi akut veya kronik olabilir ve genellikle kırıktan veya travmatik yumuşak doku yaralanmasından sonra gelişir. Supinasyon veya pronasyonda şiddetlenebilen dorsal veya volar subluksasyon gelişebilir. Distal radyoulnar eklem subluksasyonunu değerlendirmenin birkaç yöntemi vardır. Öncelikle el bileğinin gerçek arkaön ve yan radyografileri çekilmelidir, $10^{\circ}$ 'lik pronasyon veya supinasyon DRU eklemin değerlendirilmesini bozar. Gerçek yan radyografide ulna radiusun $2 \mathrm{~mm}$ dorsalinde yer almalıdır, 6 mm'den fazla fark DRU eklem instabilitesi olarak adlandırılır. Arka-ön radyografilerde ise distal radius ile ulna arasındaki aralıkta artış saptanabilir. Bilgisayarlı tomografi, DRU eklem subluksasyonunu değerlendirmek için en kullanışlı yöntemdir. El bileği nötr rotasyon, tam pronasyon ve tam supinasyonda taranmalıdır. ${ }^{25]}$ Bilgisayarlı tomografide, DRU eklem instabilitesinin değerlendirilmesi için üç farklı yöntem önerilmiştir: Mino yöntemi, uyum yöntemi ve üst merkez yöntemi. Bu üç yöntem aksiyel kesitler üzerinden değerlendirilir (Şekil 11 ve 12). ${ }^{[26]}$

\section{Ulnar Sıkışma Sendromu}

Ulnar sıkışma sendromu, kısa distal ulnanın sigmoid çentiğin proksimalindeki distal radiusa çarpmasıyla gelişen bir durumdur. ${ }^{[27]}$ Kısa ulna; negatif ulnar varyans gibi doğumsal bir anomali olabildiği gibi, büyüme plaklarının erken füzyonuna bağlı veya önceki ameliyatın bir sonucu da olabilir. Radyografide negatif ulnar varyans; distal ulnar plağın erken kapanmasına bağlı kısa ulna ve distal radiusun medial yüzünde çanaklaşma; distal ulnar rezeksiyon olgularında radyal çanaklaşma ve radyokarpal yakınlaşma izlenir. Manyetik 

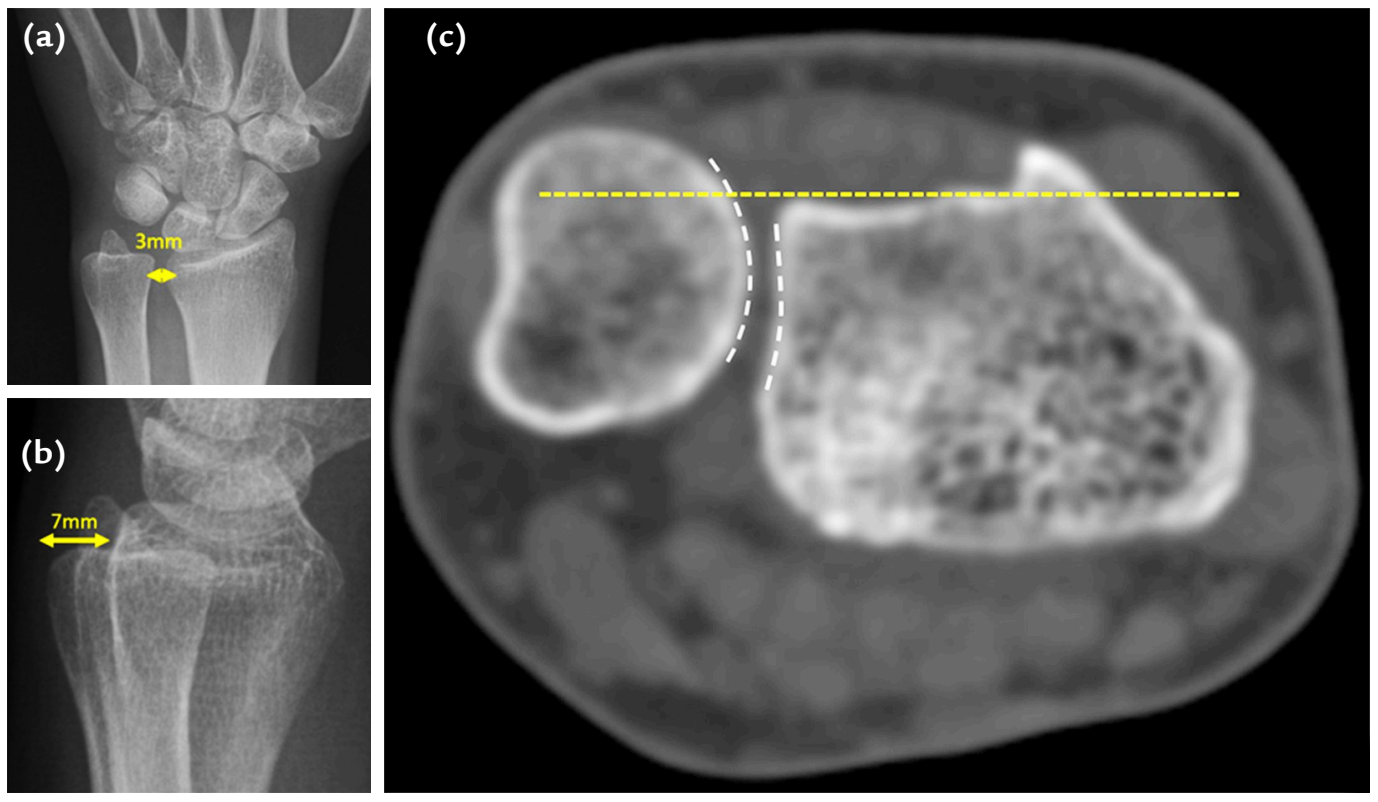

Şekil 12. a-c. Distal radyoulnar (DRU) eklem instabilitesinin radyolojik görüntülemesi: Antero-posterior (AP) pozisyon radyografisinde DRU eklemde $3 \mathrm{~mm}$ ayrışma (a), yan pozisyon radyografide $7 \mathrm{~mm}$ dorsale translasyon (b), aksiyel kesit bilgisayarlı tomografide (BT'de) dorsale translasyon (Mino yöntemi) ve ulna başı ile sigmoid çentik arasında uyumun bozulması (c).

rezonans görüntüleme ile erken tanı konabilir ve MR'de radius ve ulnanın karşılık gelen kısmında hafif skleroz ve kemik ödemi görülür. ${ }^{[19]}$

\section{Pisotrikuetral Eklem}

Pisotrikuetral eklemi etkileyebilecek bozukluklar arasında osteoartrit, enflamatuvar artrit ve eklem dengesizliği bulunur. Otuz derece supinasyonda alınan radyografilerde eklem mesafesinin daralması, erozyonları veya osteofiti gösterebilir. Manyetik rezonans görüntüleme ile subkondral ödem ve kondromalazi gibi değişiklikler tespit edilebilir. ${ }^{[28]}$

\section{Lunotrikuetral (LT) Koalisyon}

Lunotrikuetral (LT) koalisyon, tüm koalisyonlar arasında en yaygın olanıdır ve $\% 0,1^{\prime}$ lik bir insidansa sahiptir. Lunotrikuetral koalisyon 4 tipe ayrılır. Tip 1, psödoartroza benzeyen inkomplet füzyon, tip 2 kısmi kemik füzyonu ve tip 3 tam kemik füzyonu ile karakterizedir. Tip 4'te ise tip 3 füzyonla birlikte karpal anomali mevcuttur. Lunotrikuetral koalisyonun radyografik değerlendirmesi en iyi anteroposterior görünümde yapılır. Lunotrikuetral eklem alanı genellikle daralır veya bulunmaz. ${ }^{[29]}$ Bilgisayarlı tomografi ve MR ile koalisyon türü ve ilişkili komplikasyonları daha iyi değerlendirilebilir (Şekil 13).

\section{Lunotrikuetral Bağ Sorunları}

Lunotrikuetral (LT) bağ, dorsal ve volarde gerçek, proksimal fibrokartilajinöz bölgede membranöz olan bir bağdır. Volar kısım, LT bağın en güçlü kısmıdır. Lunotrikuetral bağ yırtıkları travmatik veya dejeneratif olabilir. El bileğinin ekstansiyon ve radyal deviasyona aşırı zorlanması ile oluşur. Lunotrikuetral bağ yaralanması; kısmi yırtılma, tam yırtılma, dinamik ve statik instabilite şeklinde olabilir. Lunotrikuetral bağın tam kat yırtılması, ulnakarpal ligament yaralanmasıyla birlikte olduğunda; lunat kemiğin volar fleksiyonu sonucu volar interkalar segment instabilite (VISI) gelişebilir. Lunotrikuetral bağın dejeneratif yırtıkları ulnolunat impaksiyon sendromuyla beraber görülebilir. Dejeneratif perforasyonlar genellikle bağın membranöz kısmında meydana gelir, bağın volar ve dorsal kısımları bozulmadan kalır. Kronik instabilitede LT eklemde daralma, kist formasyonu görülür (Şekil 14).

Lunotrikuetral bağ, MR görüntüleme, MR artrografi, BT artrografi veya geleneksel artrografi ile değerlendirilebilir. Geleneksel radyografiler ulnar varyansı gösterebilir, bu da yırtığın travmatik mi yoksa ulnolunat impaksiyon sendromunun bir parçası mı olduğunu ayırt etmeye yardımcı olabilir.

Manyetik rezonansta LT bağ, koronal plan görüntülemelerde delta şeklinde izlenir. Bağın görünmemesi; T2 ağırlıklı görüntülerde bağdan geçen sıvı sinyali; bağın morfolojik distorsiyonu interosseöz bağ yırtığını destekler. Manyetik rezonans artrografide LT bağ yırtıklarında kontrast maddenin defektli bölgeden, radyokarpalden midkarpal ekleme geçişi görülebilir. ${ }^{[13,30]}$ 

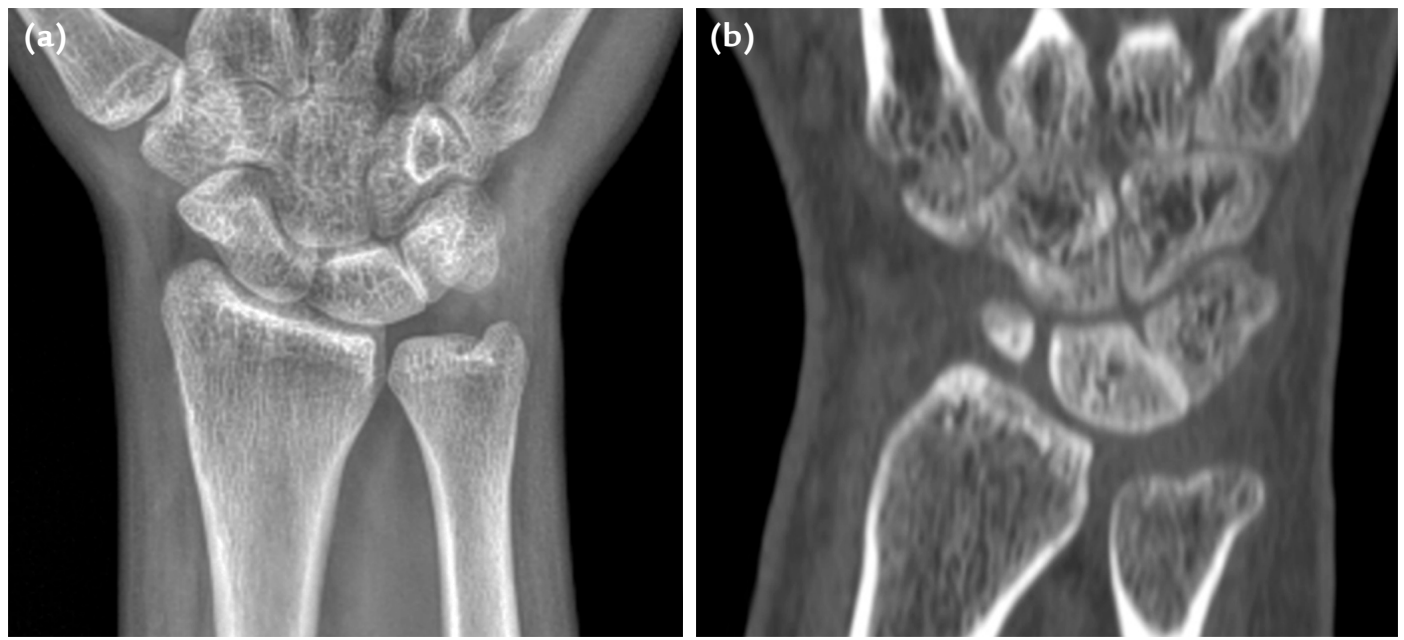

Şekil 13. a, b. Lunotrikuetral tip 2 koalisyon radyolojik görüntülemesi: Arka-ön radyografi (a) ve koronal kesit BT (b) görüntüsü. (Dr. Kahraman Öztürk'ün arşivinden izni ile alınmıştır)
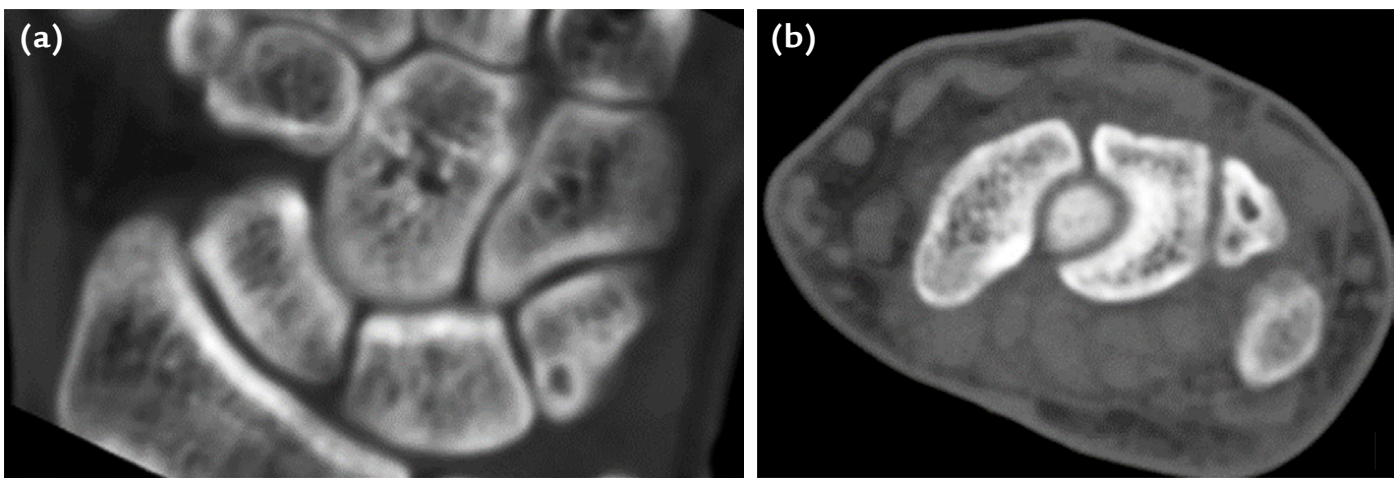

Şekil 14. a, b. Kronik lunotrikuetral (LT) instabilitede, LT eklemde artrite bağlı trikuetrum subkondral kistlerin BT görüntüsü: Koronal (A) ve aksiyel kesit (B). (Dr. Kahraman Öztürk'ün arşivinden izni ile alınmıştır)

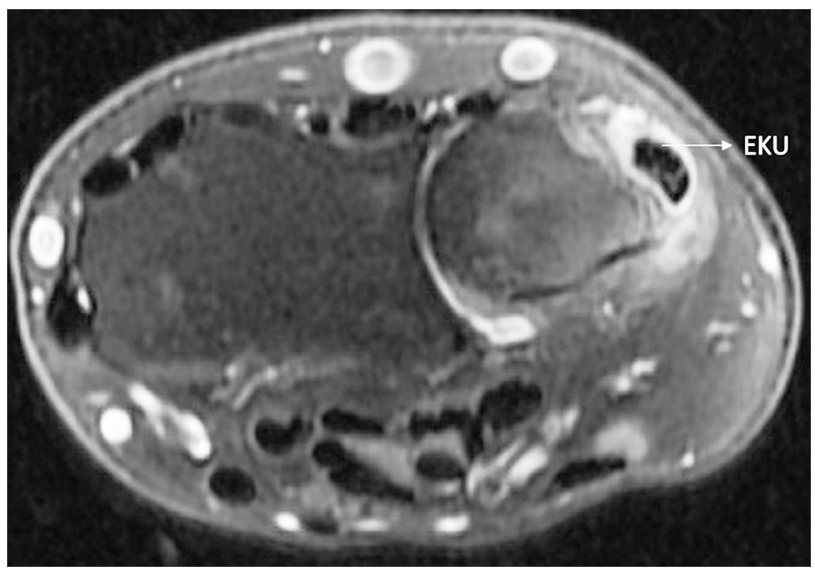

Şekil 15. Ekstansör karpi ulnaris (EKU) aksiyel yağ baskılı T2 ağırlıklı MR görüntülemesi. Ekstansör karpi ulnaris çevresinde sinovit ve EKU'nun oluğundan çıkmış olduğu görülmektedir. (Dr. Kahraman Öztürk'ün arşivinden izni ile alınmıştır)

\section{Ekstansör Karpi Ulnaris (EKU)}

Ekstansör karpi ulnaris (EKU), el bileği ulnar tarafinda, 6. ekstansör kompartmanda yer alır. Ekstansör karpi ulnaris kılıfi, TFKK'nin bir bileşenidir ve el bileği ulnar tarafının stabilize edilmesine yardımcı olur.
Ekstansör karpi ulnaris tendonu, tenosinovite ve dislokasyona eğilimlidir. Ekstansör karpi ulnaris tenosinoviti, enflamasyonla, akut travma veya tekrarlayan el bilek hareketleri sonucu oluşabilir. Ultrasonografi ve MR ile kolayca teşhis edilebilir. Manyetik rezonans T1 ağırlıklı görüntülerde tendonda çap artışı, tendon kılıfında kalınlaşma ve sıvıya bağlı düşük sinyal olarak görülür. T2 görüntülerdeyse tendon kılıfındaki sıvıya bağlı yüksek sinyal, tendonda longitudinal ayrılma ve komplet rüptür izlenebilir (Şekil 15).

Ekstansör karpi ulnaris tendon dislokasyon veya subluksasyonu, tendon kılıfında yırtık sonucu oluşur, supinasyon ve ulnar deviasyon sırasında EKU yerinden çıkar. Ultrasonografi, dinamik olarak subluksasyonu göstermesi nedeni ile MR'den daha üstündür. ${ }^{[1,6]}$

\section{KAYNAKLAR}

1. Heuck A, Bonel H, Stabler A, Schmitt R. Imaging in sports medicine: hand and wrist. Eur J Radiol 1997;26(1):2-15. Crossref

2. Steinbach LS, Palmer WE, Schweitzer ME. Special focus session. MR arthrography. Radiographics 2002;22(5):122346. Crossref 
3. Yeh GL, Beredjiklian PK, Katz MA, Steinberg DR, Bozentka DJ. Effects of forearm rotation on the clinical evaluation of ulnar variance. J Hand Surg Am 2001;26(6):1042-6. Crossref

4. Loredo RA, Sorge DG, Garcia G. Radiographic evaluation of the wrist: a vanishing art. Semin Roentgenol 2005;40(3):24889. Crossref

5. Theumann NH, Pfirrmann CW, Antonio GE, Chung CB, Gilula LA, Trudell DJ, Resnick D. Extrinsic carpal ligaments: normal MR arthrographic appearance in cadavers. Radiology 2003;226(1):171-9. Crossref

6. Wong DC, Wansaicheong GK, Tsou IY. Ultrasonography of the hand and wrist. Singapore Med J 2009;50(2):219-25. http://smj.sma.org.sg/5002/5002pe1.pdf

7. Bajaj S, Pattamapaspong N, Middleton W, Teefey S. Ultrasound of the hand and wrist. J Hand Surg Am 2009;34(4):759-60. Crossref

8. Kaewlai R, Avery LL, Asrani AV, Abujudeh HH, Sacknoff $\mathrm{R}$, Novelline RA. Multidetector CT of carpal injuries: anatomy, fractures, and fracture dislocations. Radiographics 2008;28(6):1771-84. Crossref

9. Bille B, Harley B, Cohen H. A comparison of CT arthrography of the wrist to findings during wrist arthroscopy. J Hand Surg Am 2007;32(6):834-41. Crossref

10. Moser T, Dosch JC, Moussaoui A, Buy X, Gangi A, Dietemann JL. Multidetector CT arthrography of the wrist joint: how to do it. Radiographics 2008;28(3):787-800. Crossref

11. Yoshioka H, Ueno T, Tanaka T, Shindo M, Itai Y. High-resolution MR imaging of triangular fibrocartilage complex (TFCC): comparison of microscopy coils and a conventional small surface coil. Skeletal Radiol 2003;32(10):575-81. Crossref

12. Johnson D, Stevens KJ, Riley G, Shapiro L, Yoshioka H, Gold GE. Approach to MR Imaging of the Elbow and Wrist: Technical Aspects and Innovation. Magn Reson Imaging Clin N Am 2015;23(3):355-66. Crossref

13. Braun $H$, Kenn W, Schneider S, Graf M, Sandstede J, Hahn D. [Direct MR arthrography of the wrist- value in detecting complete and partial defects of intrinsic ligaments and the TFCC in comparison with arthroscopy]. Rofo 2003;175(11):1515-24. Crossref

14. Totterman SM, Miller RJ, McCance SE, Meyers SP. Lesions of the triangular fibrocartilage complex: MR findings with a three-dimensional gradient-recalled-echo sequence. Radiology 1996;199(1):227-32. Crossref

15. Porteous R, Harish S, Parasu N. Imaging of ulnar-sided wrist pain. Can Assoc Radiol J 2012;63(1):18-29. Crossref

16. Cerezal L, Abascal F, García-Valtuille R, Del Piñal F. Wrist MR arthrography: how, why, when. Radiol Clin North Am 2005;43(4):709-31. Crossref
17. Kang HS, Kindynis P, Brahme SK, Resnick D, Haghighi P, Haller J, Sartoris DJ. Triangular fibrocartilage and intercarpal ligaments of the wrist: MR imaging. Cadaveric study with gross pathologic and histologic correlation. Radiology 1991;181(2):401-4. Crossref

18. Imaeda $\mathrm{T}$, Nakamura $\mathrm{R}$, Shionoya $\mathrm{K}$, Makino $\mathrm{N}$. Ulnar impaction syndrome: $M R$ imaging findings. Radiology1996;201(2):495-500. Crossref

19. Cerezal L, del Pinal F, Abascal F. MR imaging findings in ulnar sided wrist impaction syndromes. Magn Reson Imaging Clin N Am 2004;12(2):281-99. Crossref

20. Major NM, Anderson MW, Helms CA, Kaplan PA, Dussault R, editors. Wrist and hand. In: Musculoskeletal MRI, 3rd ed. Philadelphia: Elsevier; 2020. p.263-94. Crossref

21. Garcia-Elias M. Soft-tissue anatomy and relationships about the distal ulna. Hand Clin 1998;14(2):165-76. Crossref

22. Topper SM, Wood MB, Ruby LK. Ulnar styloid impaction syndrome. J Hand Surg Am 1997;22(4):699-704. Crossref

23. Burgess RC. Anatomic variations of the midcarpal joint. J Hand Surg Am 1990;15(1):129-31. Crossref

24. Cerezal L, del Piñal F, Abascal F, García-Valtuille R, Pereda $\mathrm{T}$, Canga A. Imaging findings in ulnar-sided wrist impaction syndromes. Radiographics 2002;22(1):105-21. Crossref

25. Chiang CC, Chang MC, Lin CF, Liu Y, Lo WH. Computerized tomography in the diagnosis of subluxation of the distal radioulnar joint. Zhonghua Yi Xue Za Zhi (Taipei) 1998;61(12):708-15. https://pubmed.ncbi.nlm.nih.gov/9884443/

26. Mino DE, Palmer AK, Levinsohn EM. The role of radiography and computerized tomography in the diagnosis of subluxation and dislocation of the distal radioulnar joint. J Hand Surg Am 1983;8(1):23-31. Crossref

27. Bell MJ, Hill RJ, McMurtry RY. Ulnar impingement syndrome. J Bone Joint Surg Br 1985;67(1):126-9. Crossref

28. Moraux A, Lefebvre G, Pansini V, Aucourt J, Vandenbussche L, Demondion X, Cotten E. Pisotriquetral joint disorders: an under-recognized cause of ulnar side wrist pain. Skeletal Radiol 2014;43(6):761-73. Crossref

29. DeVilliers Minnaar AB. Congenital fusion of the lunate and triquetral bones in the South African Bantu. J Bone Joint Surg $\mathrm{Br}$ 1952;34-B(1):45-8. Crossref

30. Zlatkin MB, Chao PC, Osterman AL, Schnall MD, Dalinka MK, Kressel HY. Chronic wrist pain: evaluation with highresolution MR imaging. Radiology 1989;173(3):723-9. Crossref 